a threefold eruption from a deep source to an intermediate level. In this case, after a partial eruption of the magma at this intermediate level, complete resorption of the barkevikite and some other minerals would take place, and the residue would differentiate under the forces of gravity into two portions. An upper portion would give rise to the dense non-porphyritic phonolites, and the lower portion would provide the basalts.

The chemical composition of the intermediate lavas, as well as their mineral composition, would suggest that the original magma was that of essexite. It is important to note that in the Island of Tahiti, where there is a similar assemblage of alkaline and basic lavas, the reservoir has been laid bare by denudation and contains essexite as the dominant rock.

\title{
OBITUARY.
}

\section{Dr. ALFRED ERNEST BARLOW, M.A., 1).Sc., F.R.S.CAN., F.G.S.A., ETC.}

BORN 1861.

DIED MAY 29, 1914.

Amongst the terrible loss of life in the St. Lawrence disaster by the sinking of the Empress of Ireland, there comes as a shock to all geologists and mining men interested in the occurrence of ore-deposits in the Archæan crystalline rocks of Canada the loss of one who, for the past thirty years, has taken a most active part in the deciphering of the structure of the earth's crust in the great crystalline areas of North A merica.

In Dr. Barlow Canada had the last court of appeal on the genesis of its ore-deposits. Trained first at home in Montreal by his father, Robert Barlow, geologist and cartographer under Sir William Logan, of the Geological Surrey of Canada, Barlow studied at McGill University under Sir William Dawson, Dr. Harrington, and other geologists, and was asked to join the technical staff of the Geological Survey of Canada in 1883, at Ottawa, under Dr. A. R. C. Selwyn. Filled with energy and enthusiasm for the science of geology, he entered the field in the province of Quebec, and later on wrought hard in the nickel and copper-bearing deposits of the Sudbury region in Ontario. His work in the area under question is a monograpl of the greatest value, and his reports and papers regarding the genesis of the nickeliferous pyrrhotite of the region, and the occurrence of the same in the various types of crystalline rocks developed during the magmatic differentiation which took place are recognized as the best and most natural and practical treatises. In the Cobalt silvermining district of Untario, throughout the Lake Temiskaming areas of crystalline rocks, in the iron-ore region of Lake Timagami, as well as in the gold-bearing rocks of the Porcupine District, on the Montreal River, and in the Haliburton and Bancroft region of Southern Ontario, throughout the Hastings Series, besides the special district of Dungannon (where corundum deposits are found), Dr. Barlow was the worker who, with unceasing energy and devotion to the 
solution of the difficult problems presented in these various fields, characterizing nearly as many petrographical provinces, has left a record of noteworthy achievement to our science. His writings are numerous and important. Fearless in all his endeavours to ascertain the truth, he published the same, as it presented itself to him, in an equally fearless fashion. Of a vigorous temperament and endowed with unbounded activity and intellectual strength. Dr. Barlow found a wide field for his geological investigations, and his reports breathe that spirit of originality, of thought, and of personal care and attention, of minute petrographical and microscopical details, which were necessary in the study of the many areas of ore-deposits entrusted to him by the various directors of the Geological Survey under whom he wrought for the past twenty-five years. It was under Dr. Selwyn and Dr. Dawson, as well as under Dr. Low, that he was enabled to do his best work. In mining centres he was the welcome geologist and friend to be consulted, and his information both in the field and in the office was the final word that gave satisfaction to the various inquiries made covering the areas above mentioned. His loss is great, and his work was thoroughly good during the brief half-centurr of his existence. At the Mareh (1914) meeting of the Canadian Mining Institute held in Montreal he was the retiring President, and he did much for the Institute and the mining fraternity to bring about close relations between the thoroughgoing geologist and the practical mining engineer, a relation of the greatest value in any community where the mineral resources of a country are of such vast import as in Canada, realizing as they do now an annual value of some $135,000,000$ dollars. During the 'Twelfth International Congress of Geology held in Canada last year Barlow was a host in himself. In him Canada has lost a diligent and successful as well as honest and fearless geologist, whose convictions went before his personal advantages or aggrandisement in an unselfish aim to bring his chosen science and its value to the State to the forefront in an unblemished career.

SEAFORD, SUSSEX.

H. M. AMr.

\section{NEWTON HORACE WINCHELL.}

BORN DECEMTBER 17, 1839.

DIED MAY 2, 1914.

Professor Newton Horace Winchell died on Saturday, May 2, in a hospital at Minneapolis (the city in which he lived). He was in active health and work up to a few days before his death (which resulted from a surgical operation). Professor Winchell was born in N.E. New York on December 17, 1839, and died in his 75 th year. His great work was as State Geologist of Minnesota, for twenty-eight years $(1872-1900)$. He was Founder and Editor of the American Geologist, which was published for eighteen years in Minneapolis (1888-1905). Since 1906 Professor Winchell was in charge of the Department of Archæology of the Minnesota Historical Society.

Minnesota Historical, Society. $\operatorname{May} 18,1914$.
WARREN UPHAM, Secretary and Librarian. 